Pemanfaatan Jurnal Online Perpustakaan BPTP Yogyakarta Dwi Titaningsih, Suharno

Kerja Sama antara SDM Perpustakaan untuk Menuju Layanan Prima dan Unggul Endang Fatmawati

Revitalisasi Peran Perpustakaan Umum bagi Masyarakat Noorika Retno Widuri

Optimalisasi Layanan Penelusuran Sumber-sumber Informasi untuk Mendukung Penulisan Karya Ilmiah Dosen dan Mahasiswa di Perguruan Tinggi Dian Hapsari

Memperkuat Peran Pustakawan dalam Mewujudkan Layanan Perpustakaan Perguruan Tinggi yang Prima dan Unggul Bambang Hermanto

Aktivitas Mahasiswa dalam Membaca Skripsi di Perpustakaan Masriyatun

Budaya Peduli dan Budaya Mutu Melayani di Perpustakaan SMP Negeri 13 Surakarta Menuju Sekolah Menyenangkan Ria Widyawati

Redesain Website UPT Perpustakaan Universitas Sebelas Maret sebagai Media Pendidikan Pengguna bagi Pemustaka Tri Hardian Satiawardana

Peran Perpustakaan dalam Membangun Citra Perpustakaan di Era Teknologi Informasi Sri Anawati

Komunitas Pustakawan Menulis (upaya menyebarluaskan dan melestarikan pengetahuan) Tri Hardiningtyas 


\section{Jurnal}

\section{Pustaka Ilmiah}

\section{Jurnal Ilmiah UPT Perpustakaan UNS}

Jurnal Pustaka Ilmiah (JPI) sebagai media kreasi para pustakawan, guru, dosen, dan praktisi dalam pengembangan profesi secara berkelanjutan. Berbagai ide dan gagasan kreatif menjadi bahan kajian yang diimplementasikan dalam berbagai model pengembangan bahan pustaka, baik cetak maupun online. Kreativitas menjadi akar pengembangan ilmu pengetahuan sepanjang hayat dengan berbagai model pengembangan budaya literasi di perpustakaan. Keindahan dan kecermatan dalam sebuah tulisan ilmiah dan nonilmiah akan dapat direalisasikan secara nyata oleh sumber daya manusia untuk menghasilkan SDM yang unggul dan kreatif dengan membaca dan menulis untuk menyinari dunia. Budaya literasi menjadi upaya untuk pengembangan dan pemberdayaan perpustakaan sebagai pusat sumber belajar untuk mendukung tri dharma perguruan tinggi.

\section{SUSUNAN REDAKSI}

Penanggung Jawab

Ketua Redaksi

Wakil Redaksi

Sekretaris

Penyunting Ahli

Penyunting

Bendahara

Sirkulasi
: Dr. Muhammad Rohmadi, M.Hum.

: Dra. Tri Hardiningtyas, M.Si.

: Haryanto, M.IP.

: Bambang Hermanto, S.Pd., M.IP., Henny Perwitosari, A.Md.

: 1. Dr. Muhammad Rohmadi, M.Hum. (Universitas Sebelas Maret);

2. Drs. Widodo, M.Soc.Sc. (Universitas Sebelas Maret);

3. Drs. Harmawan, M.Lib. (Universitas Sebelas Maret).

: Daryono, S.Sos., M.IP.; RiahWiratningsih, S.S., M.Si., Dinar Puspita Dewi, S.Sos., M.IP.; Sri Utari, S.E.

: Nurul H., A. Md.; Novi Tri Astuti, A.Md.

: Aji Hartono, A. Md.; Agus Sriyono, A.Md.; Aris Suprihadi, S.IP.

UPT PERPUSTAKAAN UNS

REDAKSI JURNAL PUSTAKA ILMIAH

Alamat: Jl. Ir. Sutami 36A Kentingan, Surakarta 57126

Telp./Fax.: (0271) 654311; email: jurnal.pustaka.ilmiah@gmail.com 


\section{Pengantar Redaksi}

\section{Salam Pustaka.}

Dengan mengucap rasa syukur kepada Allah SWT. segenap Tim Redaksi Jurnal Pustaka Ilmiah (JPI) mengucapkan banyak terima kasih kepada para penulis yang telah berkontribusi untuk penerbitan JPI volume 2 edisi Juni 2016. Penerbitan volume 2 kali ini JPI mengetengahkan tema: Pengembangan Perpustakaan menuju Layanan Prima dan Unggul. Kehadiran JPI diharapkan dapat dijadikan sebagai media penulisan bagi para pustakawan, dosen, tenaga kependidikan, guru, dan praktisi untuk menuangkan ide dan gagasan kreatifnya secara tertulis.

Dalam penerbitan JPI volume 2 bulan Juni 2016 ini disajikan sepuluh tulisan antara lain: (1) Pemanfaatan Jurnal Online Perpustakaan BPTP Yogyakarta (Dwi Titaningsih dan Suharno), (2) Kerja Sama Antara Sumber Daya Manusia Perpustakaan untuk Menuju Layanan Prima dan Unggul (Endang Fatmawati), (3) Revitalisasi Peran Perpustakaan Umum Bagi Masyarakat (Noorika Retno Widuri), (4) Optimalisasi Layanan Penelusuran Sumber-Sumber Informasi untuk Mendukung Penulisan Karya Ilmiah Dosen dan Mahasiswa di Perguruan Tinggi (Dian Hapsari), (5) Memperkuat Peran Pustakawan dalam Mewujudkan Layanan Perpustakaan Perguruan Tinggi yang Prima dan Unggul (Bambang Hemanto), (6) Aktivitas Mahasiswa dalam Membaca Skripsi di Perpustakaan FISIP-UNS (Masriyatun), (7) Budaya Peduli dan Budaya Mutu Melayani di Perpustakaan SMP Negeri 13 Surakarta Menuju Sekolah Menyenangkan (Ria Widyawati), (8) Redesain Website UPT Perpustakaan Universitas Sebelas Maret Surakarta sebagai Media Pendidikan Pengguna Bagi Pemustaka (Tri Hardian Satiawardana), (9) Peran Perpustakaan dalam Membangun Citra Perpustakaan di Era Teknologi Informasi (Sri Anawati), (10) Komunitas Pustakawan Menulis : upaya menyebarluaskan dan melestarikan pengetahuan (Tri Hardiningtyas).

Akhirnya, redaksi JPI mengucapkan banyak terima kasih kepada Kepala UPT Perpustakaan UNS yang telah memberikan dukungan dan memfasilitasi untuk penerbitan JPI. Selain itu, ucapan terima kasih juga disampaikan kepada para penulis, tim redaksi, dan Yuma Pressindo, yang telah mempersiapkan dari awal sampai terbitnya JPI. Selamat membaca.

Surakarta, Juni 2016

Ketua Redaksi 


\section{Sambutan}

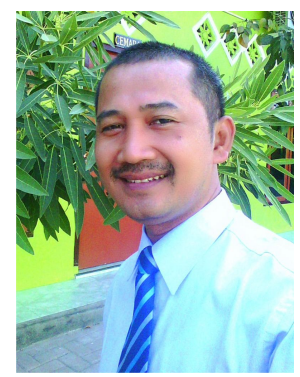

Dr. Muhammad Rohmadi, M.Hum.

\section{Kepala UPT Perpustakaan UNS}

Selamat dan sukses atas diterbitkannya kembali Jurnal Pustaka Ilmiah (JPI). Jurnal ini sebagai media kreativitas dan pengembangan softs skills para pustakawan, guru, dosen, dan praktisi untuk menuangkan ide dan gagasan demi layanan perpustakaan yang prima dan unggul. Berbagai isu terkait dengan pengembangan perpustakaan, pelayanan perpustakaan sebagai pusat sumber belajar, pendidikan, penelitian, pelestarian, dan budaya literasi akan menjadi topik-topik yang disajikan dalam jurnal ilmiah ini.

Diterbitkannya JPI sebagai bukti kepedulian UPT Perpustakaan Universitas Sebelas Maret Surakarta (UNS) dalam rangka turut berpartisipasi mengembangkan dan membudayakan literasi untuk para pustakawan dan civitas akademika di UNS maupun luar UNS. Berbagai model pengembangan softs skills menjadi alternatif untuk membekali dan memperkuat jaringan kerja sama penulisan antar kelembagaan. Dengan demikian, kerja sama antar pustakawan dan pemustaka dapat diwujudkan dengan berbagai model dalam bidang literasi.

Penerbitan JPI merupakan sarana untuk memotivasi semua pustakawan agar berkarya di bidang penulisan, baik ilmiah maupun nonilmiah. Para pustakawan harus menjadi pionir dalam bidang penulisan. Hal ini sebagai bentuk kepedulian dan keteladaan para pustakawan yang memproses, menyajikan, dan menikmati bahan-bahan pustaka cetak dan noncetak di perpustakaan. Ketersedian bahan pustaka akan menjadi bahan paling nyata untuk dikembangkan dalam berbagai model perwujudan teknik penulisan. Hal terpenting yang harus dimiliki oleh para pustakawan adalah semangat untuk berbagi pengetahuan melalui tulisan.

Kepedulian setiap sumber daya manusia kepada kelembagaan dapat dituangkan dalam berbagai model pengabdian, salah satunya adalah melalui tulisan. Berbagai ide dan gagasan dapat direalisasikan dengan berbagai model bentuk artikel jurnal, buku, modul, monograf, dan lain sebagainya. Para civitas akademika, guru, praktisi harus memiliki keterampilan menulis sebagai bentuk perwujudan pengembangan diri secara berkelanjutan. Berbagai tulisan dan referensi sudah disajikan tetapi masih sangat minim untuk diimplementasikan dalam kehidupan. Banyak orang pandai dalam berbicara tetapi masih sedikit yang menuangkan ide dan gagasannya dalam bentuk tulisan.

Akhirnya, keluarga besar UPT Perpustakaan UNS mengucapkan banyak terima kasih kepada Rektor, Wakil Rektor, pengelola JPI, penulis, dan semua pihak yang telah mendukung penerbitan JPI. Semoga dengan diterbitkannya JPI ini dapat menjadi media untuk menulis para pustakawan, dosen, guru, dan praktisi dalam bidang iptek dan seni. Ucapan terima kasih juga diucapkan kepada percetakan Yuma Pressindo yang telah membantu mempersiapkan dari awal sampai terbitnya JPI ini. Akhirnya, semoga JPI dapat memberikan nilai kemaslahatan untuk umat. 


\section{DAFTAR ISI}

\section{JURNAL PUSTAKA ILMIAH EDISI KEDUA: VOLUME 1 NOMOR 2/ JUNI 2016}

\section{Tema: Pengembangan Perpustakaan Menuju Layanan Prima dan Unggul}

Pemanfaatan Jurnal Online Perpustakaan BPTP Yogyakarta

Dwi Titaningsih, Suharno

Kerja Sama antara SDM Perpustakaan untuk Menuju Layanan Prima dan Unggul

Endang Fatmawati

Revitalisasi Peran Perpustakaan Umum bagi Masyarakat.

Noorika Retno Widuri

Optimalisasi Layanan Penelusuran Sumber-sumber Informasi untuk Mendukung Penulisan Karya Ilmiah Dosen dan Mahasiswa di Perguruan Tinggi..

Dian Hapsari

Memperkuat Peran Pustakawan dalam Mewujudkan Layanan Perpustakaan Perguruan Tinggi yang Prima dan Unggul.

Bambang Hermanto

Aktivitas Mahasiswa dalam Membaca Skripsi di Perpustakaan

Masriyatun

Budaya Peduli dan Budaya Mutu Melayani di Perpustakaan SMP Negeri 13 SurakartaMenuju SekolahMenyenangkan.

Ria Widyawati

Redesain Website UPT Perpustakaan Universitas Sebelas Maret sebagai Media Pendidikan Pengguna bagi Pemustaka.

Tri Hardian Satiawardana

Peran Perpustakaan dalam Membangun Citra Perpustakaan di Era Teknologi Informasi

Sri Anawati

Komunitas Pustakawan Menulis (upaya menyebarluaskan dan melestarikan pengetahuan)

Tri Hardiningtyas 


\title{
REDESAIN WEBSITE UPT PERPUSTAKAAN UNIVERSITAS SEBELAS MARET SEBAGAI MEDIA PENDIDIKAN PENGGUNA BAGI PEMUSTAKA
}

\author{
Tri Hardian Satiawardana \\ UPT Perpustakaan Universitas Sebelas Maret \\ Email: trihardians@staff.uns.ac.id
}

\begin{abstract}
Library website is one of the information retrieval media for students who are in the academic environment. Library website thus should adapt to the needs of students especially in conducting research. This study aimed to analyze the effectiveness of the Sebelas Maret University Library website (UNS) as library education media after the redesign. Redesigning the website focuses on how to present the information sources in which the collections of UNS Library either in printed or electronic form exists. The results of the analysis after redesigning the website showed that the use of the website is as expected. This is showed through the statistics of the web pages most frequently accessed, the number of visitors, time spent from new visitors and returning visitors to visit the Library website UNS, user behavior -especially switching between web pages-and device platform used by a visitor to visit the Library website UNS. As a conclusion, after the redesign, UNS Library website is capable of facilitating student learning behavior that is independent, techie and mobile.
\end{abstract}

Keywords: library website design, user education, user behavior

\begin{abstract}
ABSTRAK
Website perpustakaan merupakan salah satu media penelusuran informasi bagi pemustaka yang berada di lingkungan perguruan tinggi. Untuk itu, website perpustakaan sudah seharusnya menyesuaikan dengan kebutuhan pemustaka, khususnya dalam melaksanakan riset. Penelitian ini bertujuan menganalisis efektivitas website Perpustakaan Universitas Sebelas Maret (UNS) sebagai media pendidikan pengguna setelah dilakukan redesain. Redesain website difokuskan kepada bagaimana cara menyajikan sumbersumber informasi yang merupakan koleksi dan dilanggan Perpustakaan UNS, baik dalam bentuk cetak maupun elektronik. Hasil redesain website menunjukkan bahwa pola pemanfaatan website sudah sesuai dengan yang diharapkan. Hal ini ditunjukkan melalui statistik halaman web yang paling sering diakses, jumlah pengunjung, lama waktu yang digunakan new visitor dan returning visitor untuk mengunjungi website Perpustakaan UNS, perilaku pengguna, terutama perpindahan antarhalaman website dan platform perangkat yang digunakan oleh pengunjung dalam mengunjungi website Perpustakaan UNS. Kesimpulannya, setelah dilakukan redesain, website Perpustakaan UNS mampu memfasilitasi perilaku belajar mahasiswa yang mandiri, melek teknologi, dan mobile.
\end{abstract}

Kata kunci: desain website perpustakaan, pendidikan pengguna, perilaku pengguna

\section{PENDAHULUAN}

Perkembangan zaman yang disertai kemajuan teknologi turut mendorong pergeseran terhadap cara dan media penelusuran informasi. Banyaknya informasi yang tersedia mengenai sesuatu hal mengharuskan kita melakukan pencarian secara lebih selektif dan tepat sasaran. Demikian pula dalam perspektif kepustakaan. Sumber informasi tidak hanya terdapat dalam buku, tetapi juga dalam media dengan format digital. Unit Pelaksana Teknis (UPT) Perpustakaan Universitas Sebelas Maret 
(UNS) dalam hal ini juga turut menyesuaikan diri terhadap tuntutan perkembangan zaman dengan memberikan akses informasi dan koleksi kepada pemustaka, baik mahasiswa UNS maupun pengunjung umum secara daring (online). Sosialisasi mengenai cara mengakses informasi ini lazim diinisialisasi dengan bentuk pendidikan pengguna atau user education yang diberikan kepada mahasiswa baru maupun secara insidental apabila ada yang mengajukan permintaan.

Sebagai sebuah perpustakaan yang berada di perguruan tinggi, Perpustakaan UNS menyediakan beragam sumber informasi (information resources). Dengan adanya berbagai sumber informasi tersebut, wajar apabila tidak semua pemustaka memahami fasilitas yang dimiliki oleh Perpustakaan UNS. Padahal perpustakaan memiliki kewajiban untuk menyebarluaskan informasi kepada pemustaka. Dari sudut pandang ini, ada semacam celah (gap) antara perpustakaan dan pemustaka. Perpustakaan UNS sendiri sebagaimana diungkap dalam Hermanto (2014), bahwa pendidikan pengguna bagi pemustaka diperlukan, di antaranya karena pertama, sarana dan prasarana, serta koleksi di perpustakaan merupakan suatu investasi yang sangat besar bagi perguruan tinggi, oleh karena itu perpustakaan harus digunakan dan dimanfaatkan semaksimal mungkin oleh penggunanya.

Kedua, pengguna perpustakaan sebagian besar adalah mahasiswa yang ditekankan pada studi mandiri sehingga dengan kegiatan pendidikan pengguna diharapkan mahasiswa mampu lebih memahami dan menggunakan perpustakaan dengan berbagai fasilitas dan layanannya secara lebih efektif dan efisien. Dengan demikian, pendidikan pengguna, khususnya untuk mengakses sumber informasi, baik berupa buku tercetak maupun digital melalui website perpustakaan harus seluasluasnya disosialisasikan kepada pemustaka sebagai bagian dari media pembelajaran di perguruan tinggi.

Berdasarkan sumber informasi yang dimiliki Perpustakaan UNS yang bisa diakses melalui internet. Sumber informasi yang tersedia, antara lain pertama, web http:// Pustaka.uns.ac.id/ sebagai laman web utama yang menyediakan seluruh informasi mengenai Perpustakaan UNS. Web Pustaka disamping menyediakan search engine untuk penelusuran koleksi tercetak (OPAC), juga menyediakan tautan untuk mengakses e-journal dan $e$-book, baik yang dilanggan oleh Perpustakaan UNS maupun yang bisa diakses secara gratis.

Kedua, web http://unsla.uns.ac.id/ sebagai laman web untuk penelusuran koleksi tercetak dan diakses secara online dari luar Perpustakaan UNS. Unsla ini berfungsi sebagai OPAC bagi pemustaka yang hendak mencari data buku koleksi Perpustakaan UNS melalui website. Ketiga, Web OPAC UNS Library Automation (UNSLA) yang merupakan laman penelusuran koleksi tercetak yang diakses secara intranet dari dalam Perpustakaan UNS. Keempat, web https://digilib.uns.ac.id/ merupakan institutional repository yang dikembangkan sendiri oleh pengembang perangkat lunak UNS dan berisi koleksi digital tugas akhir, tesis, disertasi, dan hasil penelitian dosen, mahasiswa, dan tenaga kependidikan UNS.

Kelima, web http://eprints.uns.ac.id/ merupakan institutional repository yang menggunakan template e-prints dari University of Southampton dan digunakan sebagai repositori dalam penilaian webometric. E-prints tidak dikelola oleh Perpustakaan UNS, tetapi oleh Bagian Data dan Informasi UNS. E-prints memiliki kaitan erat dengan Digilib di mana konten dari Digilib secara terus-menerus ditransfer ke laman web E-prints. Keenam, terdapat sumber literatur lainnya, yaitu berupa jurnal yang diterbitkan oleh civitas academica UNS dan diunggah menggunakan template OJS, yaitu http://jurnal.uns.ac.id/. 
Untuk mencapai bentuk pendidikan pengguna yang ideal, terutama melalui media website, ada beberapa kelemahan yang diidentifikasi dari beragamnya sumber informasi kepustakaan di UNS ini. Pertama, pengunjung awam atau pengunjung dari luar UNS tidak mengetahui website mana yang digunakan sebagai gerbang masuk (portal) dalam penelusuran koleksi Perpustakaan UNS. Pengunjung dari yang melakukan pencarian dengan search engine di internet menggunakan kata kunci "Perpustakaan UNS" akan menemukan beberapa website, yaitu library. uns.ac.id, digilib.uns.ac.id, unsla.uns.ac.id.

Kedua, belum adanya penjelasan mengenai fungsi dari masing-masing website, sifatnya masih terpencar-pencar (scattered) dan tidak saling terkait, sehingga pengunjung sulit mengidentifikasi fungsi masing-masing website. Ketiga, belum adanya petunjuk yang komprehensif dan sifatnya mampu bertahan dalam jangka panjang (sustain) bagi pemustaka untuk membedakan kegunaan dan fungsi masing-masing laman web tersebut serta petunjuk bagaimana menggunakan masingmasing sarana penelusuran informasi tersebut.

Selanjutnya, atas pertimbangan bahwa laman web Perpustakaan UNS belum mengakomodasi beberapa hal penting yang lazimnya dimiliki oleh web perpustakaan perguruan tinggi, terutama dari perspektif pendidikan pengguna yang mandiri, mendukung repetitive learning, serta mengantisipasi kebutuhan pengguna yang sesuai dengan perkembangan teknologi informasi yang cepat, maka diperlukan desain ulang website UPT Perpustakaan UNS. Sekaligus dalam hal ini, alamat website dipindahkan dari http://pustaka. uns.ac.id menjadi https://library.uns.ac.id.

Dengan adanya permasalahn tersebut, penulis dapat merumuskan permasalahan berikut ini: bagaimana redesain website UPT Perpustakaan Universitas Sebelas Maret sebagai media pendidikan pengguna bagi pemustaka?

\section{PEMBAHASAN}

\section{Redesain Web}

Titik berat pada redesain laman website Perpustakaan UNS adalah bagaimana menyajikan informasi mengenai Perpustakaan UNS dan bagaimana pengunjung dan pemustaka memanfaatkan website ini untuk melakukan pencarian koleksi perpustakaan, baik dalam bentuk tercetak maupun elektronik.

Menurut Su dan Kuo (2010), pencarian informasi melalui media web merupakan alternatifbagi mahasiswa yang relatif disibukkan dengan berbagai kegiatan. Di samping itu, bagi perpustakaan, pencarian informasi melalui web juga menjadi keuntungan tersendiri dalam mempromosikan literasi informasi (information literacy) bagi generasi internet. Masih menurut artikel yang sama, beberapa keunggulan pencarian informasi melalui web di antaranya:

a. mahasiswa bisa menyesuaikan sendiri informasi yang akan dicarinya. Mahasiswa bisa mengatur cara belajar mereka dan menjadi pembelajar yang efektif dan mandiri,

b. terdapat banyak tutorial berbasis web yang menyediakan indeks dan daftar isi berisi tautan laman ke topik-topik yang spesifik sehingga mahasiswa bisa mendapatkan informasi yang tepat,

c. tutorial berbasis web mendukung repetitive learning yang memungkinkan mahasiswa mengulang-ulang pencarian informasi tanpa harus merasa malu apabila gagal memahami beberapa hal pada saat pertama kali mencoba mencari informasi,

Untuk memfasilitasi repetitive learning ini, menurut kami, laman web juga harus menyediakan petunjuk cara menggunakan mesin pencari, penjelasan fasilitas pencarian, dan sumber informasi elektronik yang dimiliki oleh perpustakaan, serta terdapat bagian untuk menjelaskan terminologi yang biasa digunakan di perpustakaan. 
Sementara K. Palmer (1999) (dalam Ebenezer, 2003), menekankan bahwa dalam pencarian informasi, perlu dikembangkan "penunjuk arah" (signpost) untuk meningkatkan kesadaran pengguna akan sumber-sumber informasi yang ada. Signpost tersebut berfungsi sebagai:

a. panduan ketersediaan sumber informasi dan layanan informasi pada perpustakaan dan penyedia informasi lain,

b. sebagai cara untuk menginformasikan kepada user mengenai hak mereka untuk mengakses sumber informasi dan layanan,

c. sebagai saluran di mana user diarahkan kepada titik yang tepat dalam memulai pencarian sumber informasi,

d. sebagai perangkat untuk mendidik dan mengembangkan user dalam kapasitasnya sebagai pengguna mandiri.

Artikel ini hanya membatasi pembahasan pada bentuk pendidikan pengguna melalui pemanfaatan website untuk melakukan penelusuran informasi mengenai koleksi tercetak dan elektronik.

Halaman depan atau homepage http:// pustaka.uns.ac.id/ sebagai portal menuju Perpustakaan UNS pada dunia maya awalnya didesain dengan layout sebagai berikut:

\begin{tabular}{|c|c|c|c|}
\hline Pembagian Area Web & Kiri & Tengah & Kanan \\
\hline Bagian atas (header) & $\begin{array}{l}\text { Menu-menu berupa } \\
\text { tautan: } \\
\text { 1. Profil } \\
\text { 2. Layanan } \\
\text { 3. Peraturan } \\
\text { 4. Koleksi } \\
\text { 5. Buku tamu } \\
\end{array}$ & \begin{tabular}{|l} 
1. \\
2. Slide gambar utama \\
melakukan pencarian \\
koleksi melalui OPAC, \\
namun embedded di \\
laman web, bukan \\
tautan)
\end{tabular} & $\begin{array}{l}\text { Pengumuman- } \\
\text { pengumuman }\end{array}$ \\
\hline Bagian tengah (content) & $\begin{array}{l}\text { Tautan: } \\
\text { 1. Digilib } \\
\text { 2. Free e-jurnal } \\
\text { 3. Free e-book } \\
\text { 4. OPAC }\end{array}$ & Berita dan kegiatan & $\begin{array}{l}\text { Tautan: } \\
\text { 1. artikel, } \\
\text { 2. arsip berita, } \\
\text { 3. pidato } \\
\text { pengukuhan } \\
\text { guru besar, } \\
\text { artikel } \\
\text { pustakawan }\end{array}$ \\
\hline Bagian bawah (footer) & \multicolumn{3}{|c|}{ Daftar e-jurnal dan e-book dilanggan } \\
\hline
\end{tabular}

Penjelasan pembagian area dalam website tersebut, yaitu bagian atas adalah bagian di mana user tidak perlu melakukan scroll menggunakan mouse untuk melihat informasi pada website atau merupakan bagian paling atas dari website, biasanya digunakan untuk tempat logo organisasi, menu navigasi, dan menu lain yang dianggap penting. Bagian tengah, meliputi area yang dominan dari sebuah halaman web dan beberapa informasi penting bisanya juga diletakkan pada bagian ini. Untuk halaman web yang panjang (vertikal), bagian tengah hanya membutuhkan sedikit scroll mouse. Bagian bawah merupakan bagian paling bawah dari halaman website dan biasanya berisi informasi yang sifatnya tambahan atau pelengkap.

Dari layout di atas, bisa dilihat bahwa pada sumber-sumber informasi pokok seperti tautan untuk melihat e-journal dan e-book letaknya tersebar dan tidak fokus pada area tertentu. Sedangkan untuk search tool, sudah embedded 
di website, yaitu OPAC online untuk melakukan pencarian buku tercetak yang dikoleksi oleh perpustakaan. Embedded di sini artinya adalah search engine tersebut bukan berupa tautan untuk menuju halaman berikutnya, namun sudah berupa text box, di mana pengunjung langsung menuliskan buku yang dicari menggunakan kata kunci yang lazim, seperti judul buku, pengarang, maupun subjek.

Karena dalam melakukan redesain website tidak ada kaidah baku tentang bagaimana melakukannya, kami kemudian mempelajari literatur terkait serta menggunakan perangkat lunak yang bisa, kemudian digunakan untuk sekaligus menganalisis perilaku pengguna (user's behavior) pada saat mengunjungi website Perpustakaan UNS. Ada pun perangkat lunak yang kami gunakan, yaitu Wordpress, plugin untuk menganalisis perilaku pengguna, yaitu Statistics serta aplikasi Google Analytics.

Berdasarkan penelitian yang dilakukan Singley (2014) pada 16 studi terkait pengelolaan web perpustakaan perguruan tinggi, beberapa masalah atau pertanyaan yang umumnya dijumpai oleh pemustaka pada saat mengunjungi web perpustakaan perguruan tinggi, antara lain:

a. Apa artinya itu? Beberapa masalah yang sering ditemui adalah banyaknya jargon perpustakaan (library jargon). 10 di antara 16 studi tersebut melaporkan adanya jargon perpustakaan ini. Hanya 49\% website yang tidak menampilkan jargon perpustakaan.

b. Apa yang aku cari? Pada 7 studi yang dilakukan Emily Singley, pengguna tidak memahami apa yang dicari oleh mesin pencari tersebut. Misalnya, pengguna justru menuliskan kata kunci pencarian database pada search box untuk katalog buku.

c. Di manakah aku? 6 studi menunjukkan adanya masalah (usability problem) pada saat pengguna diarahkan ke situs lain.

d. Apakah ini? Dalam memahami format bibliografi beserta kaitannya, 5 studi menemukan bahwa pengguna mengalami kesulitan memahami perbedaan antara "artikel" dan "jurnal".

e. Bagaimana aku mendapatkannya? 5 studi menemukan bahwa ada kesulitan bagi pengguna mendapatkan artikel full-text dan cara memesan buku yang tidak dimiliki oleh perpustakaan.

f. Dimanakah itu? 4 studi menunjukkan bahwa pengguna tidak memperhatikan tab yang digunakan pada saat melakukan pencarian. Hal ini bisa menjadi masalah bagi 52\% website perpustakaan yang search box-nya menggunakan tab.

Jadi, berdasarkan studi Su dan Kuo (2010), K. Palmer (1999) (dalam Ebenezer, 2003), serta Singley (2014) seperti tersebut di atas, maka desain laman web yang baru untuk mendukung unsur pendidikan pengguna yang sustain sebaiknya memenuhi kaidah-kaidah berikut. Pertama, memudahkan pemustaka maupun pengunjung untuk mencari sumber-sumber informasi, baik itu buku tercetak maupun koleksi elektronik melalui fasilitas pencarian sesuai dengan subjek yang dicari. Kemudahan tersebut juga harus disertai petunjuk penggunaan sehingga mendukung repetitive learning serta kemandirian dan mobilitas yang tinggi dalam penelusuran informasi.

Untuk memenuhi kaidah tersebut, maka langkah yang kami tempuh adalah mendesain dan me-layout ulang halaman website Perpustakaan UNS, yaitu:

a. sumber-sumber informasi ditampilkan dalam satu layout sehingga memudahkan pemustaka dan pengunjung untuk membedakan fungsi masing-masing laman web dan menentukan media yang dipakai untuk mencari sumber informasi yang relevan, baik itu buku cetak, jurnal tercetak, referensi, maupun koleksi elektronik (e-journal, e-book, dll.),

b. menu navigasi ditempatkan secara terjangkau di bagian paling atas dari website dan akan selalu berada di bagian paling atas 
(sticky) meskipun pengunjung melakukan scroll halaman web dan berpindah ke halaman lain,

c. setiap "Jargon Perpustakaan" diberi keterangan singkat mengenai maksud dari terminologi tersebut,

d. menyediakan halaman khusus yang berisi penjelasan mengenai istilah-istilah yang sering digunakan dalam kepustakaan (Library Term),

e. menyediakan halaman khusus bagaimana cara menggunakan mesin pencarian beserta penjelasan penggunaan Advanced Search, misalnya dengan operator Boolean,

f. penyediaan Search Engine untuk menelusuri koleksi tercetak dan elektronik,

g. penjelasan cara menggunakan Research Tools yang digunakan di UNS.

Kedua, website Perpustakaan UNS harus menyesuaikan diri dengan tren perkembangan website perpustakaan yang sudah maju di dunia sehingga fitur standar yang seharusnya dimiliki oleh website perpustakaan modern juga dimiliki oleh web Perpustakaan UNS. Bahwa menurut Kim (2011), desainer website boleh saja menganalisis dan meniru website perguruan tinggi lain untuk menjustifikasi bahwa website mereka memiliki kemiripan (congruent) dengan website yang baik dan sudah terkenal. Untuk itu, dilakukanlah pengamatan terhadap website perpustakaan universitas ternama di dunia yang masuk ke dalam ranking 30 besar dunia versi THES-QS Star. Peringkat universitas ini berdasarkan daftar yang diakses pada bulan April 2016 melalui laman web http://www. topuniversities.com/university-rankings/worlduniversity-rankings/2015.

Pengamatan difokuskan pada fitur yang berkaitan dengan penelusuran informasidan sarana pendukung riset yang dimiliki website perpustakaan universitas tersebut. Hasil dari pengamatan tersebut, yaitu: a. dari 30 universitas, 24 di antaranya menempatkan mesin pencarian (Search Engine Tool) pada bagian atas ataupun pada bagian yang menjadi sentral perhatian dari homepage-nya dan 1 universitas menempatkannya pada bagian tengah dari homepage-nya,

b. 20 di antaranya menyediakan Research Guide atau research tool pada bagian atas dari homepage-nya,

c. 14 di antaranya menyediakan menu Ask Librarian ataupun informasi mengenai cara penggunaan perpustakaan,

d. 9 di antaranya menyediakan tautan untuk mengakses E-Resources dan Database.

Untuk itu, desain baru website Perpustakaan UNS juga menyediakan mesin pencarian untuk penelusuran koleksi, menyediakan informasi mengenai riset, Ask Librarian, dan cara penggunaan perpustakaan (keanggotaan dan sirkulasi), serta menyediakan tautan E-resources.

Ketiga, website perpustakaan harus mampu memberikanfeedback baik kepada administrator web khususnya dan perpustakaan pada umumnya sebagai acuan untuk memperbaiki pelayanan (continuous improvement), baik bagi pengunjung maya maupun pengunjung perpustakaan itu sendiri. Untuk memfasilitasi hal ini, di website Perpustakaan UNS diberikan fitur buku tamu (guest book). Di samping menampung saran pengunjung, buku tamu juga dimanfaatkan untuk memberikan jawaban atas pertanyaan-pertanyaan pengunjung.

Hasil desain ulang web perpustakaan tersebut di atas adalah layout dan pembagian halaman depan web (homepage) https://Library. uns.ac.id/ sebagai berikut: 


\begin{tabular}{|c|c|}
\hline Pembagian Area Web & Isi \\
\hline Bagian atas & $\begin{array}{l}\text { 1. Menu navigasi, sifatnya tetap berada pada bagian paling atas web (sticky) } \\
\text { pada setiap halaman berupa dropdown menu: } \\
\text { - Research, terdiri atas: tautan search engine, e-resources, cara mencari } \\
\text { koleksi perpustakaan (Exploring Collections), panduan riset (Research } \\
\text { Guide), cara menggunakan Research Tool (Using Research Tool), dan } \\
\text { istilah perpustakaan (Library Terms). } \\
\text { - Service, terdiri dari: peminjaman dan pengembalian, serta keanggotaan } \\
\text { (Borrow Books), peminjaman khusus (Special Loan), dan fasilitas } \\
\text { perpustakaan (Facility). } \\
\text { - Ask Librarian, terdiri dari menu koleksi: umum, agama, dan filsafat; } \\
\text { sosial, humaniora, ekonomi, dan pendidikan; sains, teknologi, dan } \\
\text { kesehatan; seni, budaya, dan desain; koleksi serial dan referensi; } \\
\text { koleksi hibah dan elektronik; serta koleksi Closed Reserve. } \\
\text { 2. Gambar utama } \\
\text { 3. Berita dan agenda kegiatan }\end{array}$ \\
\hline Bagian tengah & $\begin{array}{l}\text { Tab menu, terdiri dari: } \\
\text { 1. UNS One Search, penelusuran semua koleksi UNS yang terdiri koleksi } \\
\text { tercetak, tugas akhir, tesis dan disertasi. UNS One Search Embedded di } \\
\text { dalam web sehingga pengunjung langsung mengetikkan kata kunci tanpa } \\
\text { harus masuk ke halaman yang lain } \\
\text { 2. Direct Search, yaitu tautan ke Search Engine yang sudah ada dan spesifik, } \\
\text { yaitu: } \\
\text { - OPAC (http://unsla.uns.ac.id) } \\
\text { - Digital library (https://digilib.uns.ac.id) } \\
\text { - Institutional repository (http://eprints.uns.ac.id) } \\
\text { 3. Tautan cara melakukan penelusuran koleksi melalui OPAC dan Digital } \\
\text { library. } \\
\text { 4. Tautan menuju mesin pencarian luar, yaitu Katalog Induk Nasional (KIN) } \\
\text { dan Indonesia One Search. } \\
\text { Serta tautan e-journal dan e-book, baik yang dilanggan, gratis, maupun jurnal } \\
\text { terbitan UNS (http://jurnal.uns.ac.id) }\end{array}$ \\
\hline Bagian bawah & $\begin{array}{l}\text { Informasi tambahan berupa alamat Perpustakaan UNS, jam buka, direktori } \\
\text { gedung, dan sosial media }\end{array}$ \\
\hline
\end{tabular}

Homepage dalam hal ini tidak berisi informasi detail, tetapi hanya berisi tautan karena sesuai dengan definisi homepage di Wikipedia (2016) bahwa homepage digunakan untuk memfasilitasi navigasi menuju halaman lain dalam suatu website dengan cara menyediakan tautan ke halaman yang penting dan artikel terkini.
Salah satu fitur yang bersifat hampir mandatory dalam website perpustakaan perguruan tinggi, yaitu fasilitas pencarian koleksi. Dalam hal ini, di web Perpustakaan UNS dikembangkan fasilitas UNS One Search. Konsep dari UNS One Search adalah mesin pencarian informasi untuk menelusuri seluruh koleksi yang dimiliki Perpustakaan UNS dalam satu kali pencarian. Mesin pencari ini dibangun terintegrasi (embedded) dengan laman web 
Perpustakaan UNS menggunakan software open source Yacy. Mesin ini bisa di-setting untuk melakukan crawl hanya pada website tertentu. Untuk keperluan ini, Yacy di-setting hanya untuk menelusuri halaman web unsla.uns. ac.id (koleksi tercetak), digilib.uns.ac.id, dan eprints.uns.ac.id (repositori skripsi, tesis, dan disertasi) serta jurnal.uns.ac.id (jurnal online dari Civitas Academica UNS). Hasil pencarian tidak dikelompokkan (bento) menurut sumber asal informasi tersebut, namun pengguna bisa melakukan filter sendiri untuk memilih salah satu di antara sumber asal informasi tersebut. Dalam konteks penyajian hasil pencarian Search Engine website perpustakaan, pengelompokan berdasarkan sumber asal informasi ini lebih dikenal dengan Bento (Singley, 2016).

\section{Data Pengunjung di Website Perpustakaan UNS}

Setelah dilakukan redesain terhadap website Perpustakaan UNS, langkah berikutnya adalah redesain tersebut. Hal ini diperlukan sebagai dasar pertimbangan untuk melakukan perbaikan kembali di masa yang akan datang dan menyesuaikan kebutuhan pengguna. Berdasarkan Yang dan Perrin (2013), untuk melakukan analisis terhadap website perpustakaan, langkah-langkahnya, yaitu (a) memilih jangka waktu tertentu, (b) memutuskan apa saja yang harus dianalisis, (c) menggunakan in-page analytics, (d) melakukan rekapitulasi statistik. Namun, dalam analisis ini, dilakukan beberapa penyesuaian menurut kondisi yang ada di dalam Perpustakaan UNS.

Untuk melakukan evaluasi terhadap perilaku pemustaka dan pengunjung website Perpustakaan UNS yang dibangun dengan platform Wordpress, kami menggunakan Google Analytics serta Plugin Wordpress, yaitu Statistics. Penggunaan kedua tool ini kami sesuaikan untuk masing-masing parameter dan pada tiap parameter tidak menggunakan kedua tool tersebut pada saat yang bersamaan. Data dikumpulkan mulai pada saat website diluncurkan, yaitu tanggal 30 Maret 2016 hingga 30 April 2016. Sedangkan parameter yang akan dianalisis, meliputi peringkat halaman web yang paling sering diakses, jumlah pengunjung, lama waktu yang digunakan new visitor, dan returning visitor untuk mengunjungi website Perpustakaan UNS, perilaku pengguna, terutama perpindahan antarhalaman website dan terakhir adalah platform yang digunakan oleh user dalam mengunjungi website Perpustakaan UNS. Hasil evaluasi kami jabarkan dalam paragraf berikut.

Pertama, sepuluh peringkat teratas halaman web yang paling sering diakses, data diambil menggunakan plugin Statistics, yaitu:

a. Homepage dengan 5812 kunjungan,

b. E-Journal, yaitu halaman berisi e-journal yang dilanggan oleh Perpustakaan UNS, 650 kunjungan,

c. Free E-Journal, yaitu halaman yang berisi e-journal Open Access, 394 kunjungan,

d. How to Explore Library Collection, yaitu halaman berisi penjelasan cara melakukan pencarian menggunakan OPAC Unsla dan digital library (Digilib), 236 kunjungan,

e. E-Book, yaitu halaman yang berisi e-book yang dilanggan Perpustakaan UNS, 210 kunjungan,

f. Free E-Book, halaman yang berisi e-book open access, 169 kunjungan,

g. Guest Book, yaitu halaman berisi respons dan tanggapan serta pertanyaan dari pengunjung website, 153 kunjungan,

h. Meet The Team, yaitu halaman berisi profil staf Perpustakaan UNS, 150 kunjungan,

i. berita mengenai pemenang lomba cipta puisi Hari Kartini, 134 kunjungan,

j. Borrow Books, yaitu halaman mengenai tata cara dan prosedur keanggotaan, serta peminjaman buku, 116 kunjungan. Dengan melihat hasil halaman yang paling sering dikunjungi, terlihat bahwa pengunjung website perpustakaan membutuhkan 
informasi mengenai riset dan cara penelusuran informasi secara online.

Dengan demikian, penempatan tautan terkait E-Journal, E-Book, serta penjelasan cara penggunaan Search Engine dalam pencarian koleksi perpustakaan di halaman depan homepage Perpustakaan UNS, sudah tepat dan direspons dengan baik oleh pengunjung.

Di samping itu, halaman yang erat terkait dengan kebutuhan riset bagi pemustaka, yaitu halaman Library Terms (menjelaskan istilahistilah yang sering dipakai dalam perpustakaan) serta Using Research Tool (cara menggunakan Software Riset, dalam hal ini TurnItIn), cukup sering dikunjungi dengan menduduki peringkat ke 19 dan 20. Hal ini mengindikasikan bahwa pengguna sudah semakin kritis, mandiri, dan memiliki keingintahuan yang baik dalam menggunakan media penelusuran informasi.

Hal menarik lain yang harus dicatat adalah bahwa pengunjung cukup merespons adanya buku tamu di mana peringkat kunjungan buku tamu ada di posisi ke-7 dengan 153 kunjungan, meskipun hingga batas waktu pengamatan selama 31 hari sudah berakhir hanya ada 6 pengunjung yang menuliskan pesan di buku tamu.

Diantara respons dalam buku tamu, salah satu pengunjung mengapresiasi keberadaan website Perpustakaan UNS beserta menu yang disediakan untuk menunjang riset, sebagai berikut:

Dita Miladina from Semarang wrote on 6 April 2016 at $1: 59$ pm:

Website yang bagus dan terima kasih karena ada layanan Ask Librarian, karena sebenarnya ada yang ingin saya tanyakan (:) apakah perpustakaan UNS memiliki Pathfinder? Akan sangat senang apabila pertanyaan ini mendapat tanggapan, karena hal ini berkenaan dengan penelitian yang sedang saya lakukan. terimakasih sebelumnya :-;
Kedua, data dari plugin Statistics, jumlah pengunjung, yaitu 32.617 kunjungan (Visit) yang berasal dari 7449 pengunjung (Visitor), selama 31 hari, yaitu rata-rata 1052,16 kunjungan per hari.

Apabila dilihat dari grafik di atas, antara jumlah pengunjung (Visitor, grafik bagian bawah) dan kunjungan (Visit, grafik bagian atas) terdapat fluktuasi di mana jumlah pengunjung relatif konstan, sedangkan jumlah kunjungan kadang mencapai 1800, namun kadang hanya bisa mencapai di bawah 400 kunjungan. Hal ini menunjukkan bahwa web Perpustakaan UNS masih belum bisa menarik minat pengunjung baru yang ditunjukkan dalam grafik bahwa jumlah pengunjung relatif stabil. Namun demikian, pengunjung yang serius menghabiskan relatif lebih banyak waktu untuk mengeksplorasi laman web Perpustakaan UNS seperti ditunjukkan dalam data selanjutnya.

Ketiga, dari data dari Google Analytics menunjukkan bahwa terdapat 64,49\% New Visitor dan 35,51\% Returning Visitor. Setiap sesi, user rata-rata mengunjungi 2,43 halaman dengan rata-rata tiap sesi mencapai 3 menit 55 detik. Apabila ditelusuri lebih detail, waktu yang dihabiskan oleh New Visitor untuk mengunjungi web Perpustakaan UNS adalah rata-rata 3 menit 4 detik dengan rerata halaman yang dikunjungi, yaitu 2,3 halaman. Sedangkan Returning Visitor menghabiskan waktu lebih banyak, yaitu rata-rata 5 menit 28 detik, dengan rerata halaman yang dikunjungi, yaitu 2,68 halaman. Hal ini artinya pengunjung yang serius dalam mencari informasi melalui web Perpustakaan UNS akan kembali mengunjungi laman web dan menghabiskan waktu lebih lama, serta mengeksplorasi lebih banyak halaman.

Namun demikian, jika melihat rerata waktu kunjungan yang hanya 3 menit 55 detik, hal ini masih mengindikasikan bahwa pengunjung belum memanfaatkan waktu yang cukup untuk mempelajari informasi yang ada di website. Hal ini apabila dibandingkan 
dengan data dari Zickuhr, et.al (2012) bahwa seiring dengan meningkatnya produksi $E$-Book Reader di Amerika Serikat, kunjungan ke laman web Perpustakaan untuk mencari E-Book juga meningkat. Pengunjung rata-rata menghabiskan waktu 9 menit 34 detik untuk melihat-lihat halaman web perpustakaan. Atau terdapat kemungkinan lain, yaitu bahwa web Perpustakaan UNS belum mampu memberikan informasi yang lebih beragam dan lengkap sehingga belum bisa menarik minat pengunjung untuk bertahan lebih lama.

Keempat, data Google Analytics pada menu Behavior Flow menunjukkan bahwa pengunjung yang serius dalammencari informasi, menelusuri website Perpustakaan UNS, dan mengunjungi laman untuk menunjang riset. Pola kunjungan ini, di antaranya: pertama mengunjungi Homepage, kemudian mengunjungi laman e-journal, kemudian kembali lagi ke Homepage atau ada yang melanjutkan mengunjungi laman Free E-Journal dan kembali lagi ke Homepage. Beberapa pengunjung juga mengunjungi laman How to Explore Library Collection terlebih dahulu atau mengunjungi laman ini setelah mengeksplorasi E-Journal dan E-Book.

Hal ini menunjukkan bahwa beberapa pengunjung yang serius, menelusuri website Perpustakaan dan melakukan penelusuran pada halaman web yang mendukung penelitiannya. Dengan demikian, kaidah Repetitive Learning ternyata bisa dibuktikan melalui informasi Behavior Flow. Namun demikian, penelitian ini belum bisa meneliti apakah seorang pengunjung kembali lagi mengunjungi website Perpustakaan UNS dan mengulang penelusuran informasi dengan cara mengunjungi halaman terkait riset secara bolak-balik.

Kelima, berdasarkan data dari plugin Statistics, platformsistemoperasiyangdigunakan untuk mengunjungi website perpustakaan, yaitu peringkat (1) Windows, sebanyak $68 \%$, (2) Android, sebanyak 21\%, dan (3) lain-lain, di antaranya Macintosh, Linux, Iphone, Ipad,
Blackberry, dan Windows Phone, sebanyak $11 \%$. Dari data ini, bisa dilihat bahwa paling sedikit $21 \%$ pengunjung mengakses laman web Perpustakaan UNS menggunakan aplikasi dari perangkat mobile. Selain karena sifatnya yang praktis, seperti yang sudah ditunjukkan pada data ketiga di atas, waktu rata-rata kunjungan ke laman web Perpustakaan UNS juga relatif masih singkat. Hal ini menunjukkan bahwa perilaku pengguna dalam mencari informasi juga semakin mobile sehingga perlu diantisipasi desain web yang Mobile-Friendly. Apabila dilakukan tes terhadap Mobile-Friendliness website Perpustakaan UNS melalui alamat web Google https://www.google.com/webmasters/ tools/mobile-friendly/? url=library.uns.ac.id hasilnya adalah website Perpustakaan UNS sudah mobile-friendly.

Sebagai catatan tambahan pada penelitian ini bahwa website Perpustakaan UNS hingga saat ini masih terus dalam pengembangan dengan beberapa menu yang sedang dalam tahap penyusunan. Menu-menu tersebut, yaitu Research Guide, yang berisi panduan lengkap cara melakukan riset dari perspektif pemberdayaan informasi melalui website Perpustakaan UNS. Menu selanjutnya adalah Ask Librarian yang akan diintegrasikan dengan Pathfinder untuk menyediakan rujukan pustaka tercetak maupun elektronik bagi pemustaka yang akan mengadakan penelitian pada suatu subjek tertentu. Menu Using Research Tool juga masih perlu dilengkapi karena research tool ragamnya sangat banyak.

\section{PENUTUP}

Setelah dilakukan redesain website Perpustakaan UNS, statistik yang tercatat menunjukkan bahwa website sudah cukup mampu mengarahkan pengunjung untuk terfokus pada fitur-fitur web yang terkait penelitian. Hal ini sudah sesuai dengan fungsi dari website perpustakaan perguruan tinggi sebagai pendukung kegiatan riset mahasiswa 
dengan mengacu pada Undang-Undang nomor 43 tahun 2007 tentang Perpustakaan pasal 19 dan 24.

Beberapa parameter yang sudah dipenuhi dalam redesain web ini, yaitu sudah tersedianya informasi mengenai cara menelusuri koleksi perpustakaan yang sustain, mendukung pencarian informasi secara mandiri dan mendukung repetitive learning, sumber-sumber informasi terfokus dan mengelompok dalam website, mewadahi feedback dari pengunjung, serta mobile-friendly.
Sedangkan kelemahannya, yaitu visitor relatif konstan dan belum menghabiskan waktu yang cukup memadai untuk menyerap informasi yang terdapat dalam website Perpustakaan UNS. Dengan demikian, penelitian ini masih membuka kesempatan dilanjutkannya perbaikan pada desain dan konten website itu sendiri maupun penelitian perilaku pengunjung dalam mencari informasi koleksi yang dimiliki perpustakaan.

\section{DAFTAR PUSTAKA}

Ebenezer, Catherine. 2003. "Usability Evaluation of an NHS Library Website". Health Information and Libraries Journal.

Hermanto, Bambang. 2014. "Pendidikan Pengguna Perpustakaan Sebuah Peluang atau Tantangan Di UPT Perpustakaan UNS”. Diakses 18 April 2016 dari https://digilib.uns.ac.id/dokumen/ detail/42170/Pendidikan-Pengguna-Perpustakaan-Sebuah-Peluang-atau-Tantangan-DiUPT-Perpustakaan-UNS

Kim, Yong-Mi. 2011. "Factors Affecting University Library Website Design". Information Technology and Libraries.

Republik Indonesia. 2007. Undang-Undang NoMOR 43 Tahun 2007 tentang Perpustakaan. Lembaran Negara RI Tahun 2007, No. 129. Jakarta: Sekretariat Negara.

Singley, Emily. 2014. "Top 5 Problems with Library Websites - A Review Of Recent Usability Studies". Diakses 8 April 2016 dari http://emilysingley.net/top-5-problems-with-librarywebsites-a-review-of-recent-usability-studies/.

. 2016. "To Bento or Not to Bento - Displaying Search Results". Diakses 8 April 2016 dari http://emilysingley.net/to-bento-or-not-to-bento-displaying-search-results/.

Su, Shiao-Feng dan Kuo, Jane. 2010. "Design and Development of Web-Based Information Literacy Tutorials". The Journal of Academic Librarianship.

Wikipedia. 2016. “Homepage”. Diakses 30 April 2016 dari https://en.wikipedia.org/wiki/Home_ page.

Yang, Le dan Perrin, Joy Marie. 2013. "Tutorials on Web Analytics: How to Conduct a Web Analytics Report on the Library Website". Diakses 2 Mei 2016 dari https://secure.txla.org/ secure/events/handouts/2014/486cTutorials_on_Web_Analytics.pdf

Zickuhr, Kathryn, Rainie,L., Purcell, K., Madden, M., dan Brenner, J.. 2012. "Libraries, patrons, and e-books: Part 1: An introduction to the issues surrounding libraries and e-books". Diakses 2 Mei 2016 dari http://libraries.pewinternet.org/2012/06/22/part-1-an-introductionto-the-issues-surrounding-libraries-and-e-books/. 